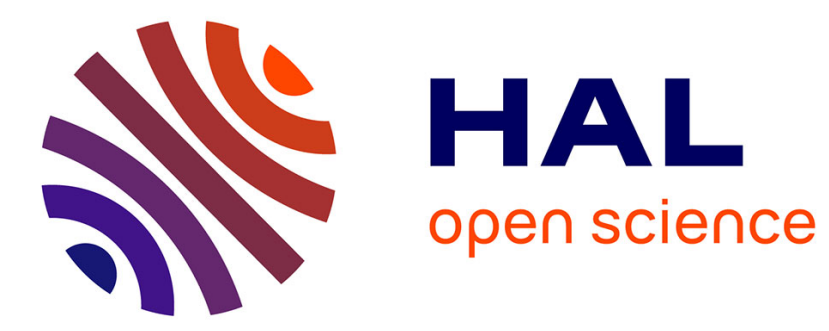

\title{
Stannyl-substituted Disilenes and a Disilastannirane
}

\author{
Kai Abersfelder, Nguyen Thi-Loan, David Scheschkewitz
}

\section{To cite this version:}

Kai Abersfelder, Nguyen Thi-Loan, David Scheschkewitz. Stannyl-substituted Disilenes and a Disilastannirane. Journal of Inorganic and General Chemistry / Zeitschrift für anorganische und allgemeine Chemie, 2009, 635 (13-14), pp.2093. 10.1002/zaac.200900234 . hal-00510610

\section{HAL Id: hal-00510610 https://hal.science/hal-00510610}

Submitted on 20 Aug 2010

HAL is a multi-disciplinary open access archive for the deposit and dissemination of scientific research documents, whether they are published or not. The documents may come from teaching and research institutions in France or abroad, or from public or private research centers.
L'archive ouverte pluridisciplinaire HAL, est destinée au dépôt et à la diffusion de documents scientifiques de niveau recherche, publiés ou non, émanant des établissements d'enseignement et de recherche français ou étrangers, des laboratoires publics ou privés. 


\section{Stannyl-substituted Disilenes and a Disilastannirane}

\begin{tabular}{|r|l|}
\hline Journal: & Zeitschrift für Anorganische und Allgemeine Chemie \\
\hline Manuscript ID: & zaac. 200900234.R1 \\
\hline Wiley - Manuscript type: & Article \\
\hline Date Submitted by the \\
Author: & 05-Jun-2009 \\
\hline Complete List of Authors: & $\begin{array}{l}\text { Abersfelder, Kai; Imperial College London, Department of } \\
\text { Chemistry } \\
\text { Thi-loan, Nguyen; Imperial College London, Department of } \\
\text { Chemistry } \\
\text { Scheschkewitz, David; Imperial College, Department of Chemistry }\end{array}$ \\
\hline Keywords: & $\begin{array}{l}\text { Group 14 elements, Metallacycles, Multiple bonds, Silicon, } \\
\text { Stannanes }\end{array}$ \\
\hline
\end{tabular}

\section{s scholarONE \\ Manuscript Central}




\title{
ARTICLE
}

DOI: 10.1002/zaac.200((will be filled in by the editorial staff))

\section{Stannyl-substituted Disilenes and a Disilastannirane}

\author{
Kai Abersfelder, ${ }^{[\mathrm{a}]}$ Thi-loan Nguyen ${ }^{[\mathrm{a}]}$ and David Scheschkewitz ${ }^{*[\mathrm{a}]}$
}

Dedicated to Prof. Dr. Michael Veith on the occasion of his $65^{\text {th }}$ birthday

Keywords: Group 14 elements; Metallacycles; Multiple bonds; Silicon; Stannanes

Abstract. The reaction of disilenide $\mathrm{Tip}_{2} \mathrm{Si}=\mathrm{Si}$ (Tip)Li (1, Tip = 2,4,6- ${ }^{i} \mathrm{Pr}_{3} \mathrm{C}_{6} \mathrm{H}_{2}$ ) with chlorostannanes $\mathrm{R}_{3} \mathrm{SnCl}$ quantitatively affords the first stannyl substituted disilenes $\mathrm{Tip}_{2} \mathrm{Si}=\mathrm{Si}(\mathrm{Tip}) \mathrm{SnR}_{3}(\mathbf{2 a}: \mathrm{R}=$ Me, 2b: $\mathrm{R}=\mathrm{Bu}, \mathbf{2 c}: \mathrm{R}=\mathrm{Ph}$ ). The $S n$-functional derivative $\mathrm{Tip}_{2} \mathrm{Si}=\mathrm{Si}(\mathrm{Tip}) \mathrm{Sn}^{t} \mathrm{Bu}_{2} \mathrm{Cl}(\mathbf{3})$ is accessible in good yield from $\mathbf{1}$ and ${ }^{t} \mathrm{Bu}_{2} \mathrm{SnCl}_{2}$.

* Dr. D. Scheschkewitz

Fax: (+44)20-7594-5804

E-mail: d.scheschkewitz@imperial.ac.uk

[a] Department of Chemistry, Imperial College London, South Kensington Campus, Exhibition Road

London SW7 2AZ (UK)

\section{Introduction}

Organotin compounds are widely applied in synthetic organic chemistry. The palladium-catalysed coupling of organotin reagents with a variety of organic substrates (Stille coupling) allows for the generation of $\mathrm{sp}^{2}-\mathrm{sp}^{2}$ carboncarbon linkages under mild and neutral conditions; a broad variety of unprotected functional groups on both coupling partners are tolerated.[1] The transmetallation of tin organyls is a useful tool for the preparation of organo lithium species, e.g. vinyl lithiums[2] or allyl lithiums.[3]

During the last five years we and others have reported a variety of disilenides, disila analogues of vinyl anions. [4,5] The rising interest in this class of compounds stems from their ability to transfer the $\mathrm{Si}=\mathrm{Si}$ double bond to organic and inorganic substrates.[5a,5d,5g;6] In order to broaden the scope of the $\mathrm{Si}=\mathrm{Si}$ transfer, the preparation of a range of hitherto unknown stannyl substituted disilenes appeared desirable and will be reported here. Additionally, we discuss the preparation of an $S n$-chlorinated derivative, a chlorostannyl disilene, as well as that of a related saturated cyclic compound, a disilastannirane.

\section{Results and Discussion}

The reactions of disilenide 1 with $\mathrm{R}_{3} \mathrm{SnCl}$ or ${ }^{t} \mathrm{Bu}_{2} \mathrm{SnCl}_{2}$ in hexane or toluene lead to stannyl substituted disilenes 2a-c (a: $\mathrm{R}=\mathrm{Me}, \mathrm{b}: \mathrm{R}=\mathrm{Bu}, \mathbf{c}: \mathrm{R}=\mathrm{Ph}$ ) and 3 (Scheme 1). The products were isolated in yields between $59 \%$ and $95 \%$ after crystallisation from hexane and characterised by

\begin{abstract}
Additionally, the first heavy analogue of cyclopropanes containing two endocyclic silicon and one tin atom was prepared from 1 and $\mathrm{Me}_{2} \mathrm{SnCl}_{2}$. All new compounds were characterised by multinuclear NMR spectroscopy and the thus deduced structural assignments corroborated by single crystal X-ray diffraction.
\end{abstract}

multinuclear NMR spectroscopy. Single crystals of $\mathbf{2 a}$ and $\mathbf{3}$ were analysed by X-ray diffraction.

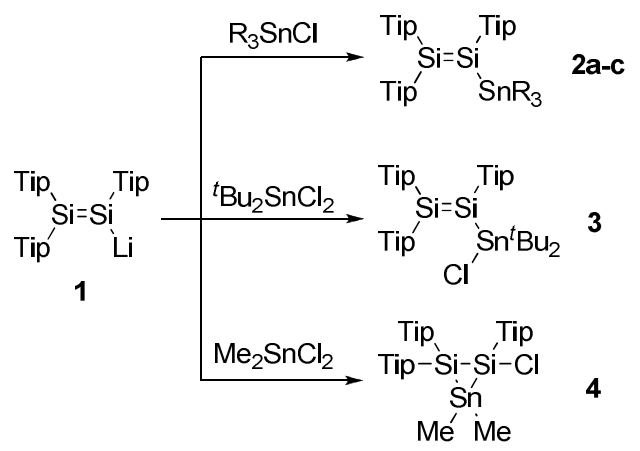

Scheme 1. Syntheses of stannyl disilenes 2a-c $(\mathbf{a}: \mathrm{R}=\mathrm{Me}, \mathbf{b}: \mathrm{R}=$ $\mathrm{Bu}, \mathbf{c}: \mathrm{R}=\mathrm{Ph}$ ) and 3 as well as disilastannirane 4 (Tip $=2,4,6-$ ${ }^{i} \operatorname{Pr}_{3} \mathrm{C}_{6} \mathrm{H}_{2}$ ).

The ${ }^{119} \mathrm{Sn}$ NMR resonances of $\mathbf{2 a - c}$ from $\delta=-52.9$ to $-108.9 \mathrm{ppm}$ are found in the expected range for tetracoordinated tin atoms (Table 1). The chemical shifts in the ${ }^{29} \mathrm{Si}$ NMR chemical shifts of the stannyl disilenes 2a-c between $\delta=113.3$ and $103.4 \mathrm{ppm}$ for the $\mathrm{SiTip}_{2}$ moiety and $\delta=38.9$ and $30.4 \mathrm{ppm}$ for the tin-bonded silicon atom are similar to those of the monosilyl disilenes we had reported earlier.[5a,6e] All signals were unambiguously assigned with the help of ${ }^{29} \mathrm{Si},{ }_{1}^{1} \mathrm{H}$ 2D-NMR spectra and show well resolved ${ }^{119} \mathrm{Sn}-{ }^{29} \mathrm{Si}$ coupling patterns. For all stannyl disilenes 2a-c the ${ }^{1} \mathrm{~J}\left({ }^{119} \mathrm{Sn} /{ }^{29} \mathrm{Si}\right)$ coupling constants are between 3.5 and 4.0 times larger than the corresponding ${ }^{2} \mathbf{J}$ values.

The UV/vis spectra of 2a-c are very similar to that of the monosilyl substituted disilenes as well (Table 1). The extinction coefficients range from $\varepsilon=8300$ to 10000 . 
Table 1. Comparison of ${ }^{29} \mathrm{Si}$ NMR and UV-Vis Data of Stannyl Disilenes $2 \mathbf{a}, \mathbf{2 b}, \mathbf{2 c}$ and $\mathbf{3}$.

\begin{tabular}{lllll}
\hline & 2a & 2b & 2c & $\mathbf{3}$ \\
\hline$\delta^{29} \mathrm{Si} 1, \mathrm{ppm}$ & 38.9 & 36.8 & 30.4 & 40.9 \\
$\delta^{29} \mathrm{Si} 2, \mathrm{ppm}$ & 103.4 & 105.3 & 113.3 & 114.5 \\
$\delta^{119} \mathrm{Sn}, \mathrm{ppm}$ & -68.3 & -52.9 & -108.9 & 109.5 \\
${ }^{1} J_{\mathrm{Sn}, \mathrm{Si}}, \mathrm{Hz}$ & 474.2 & 353.6 & 480.7 & 88.4 \\
${ }^{2} J_{\mathrm{Sn}, \mathrm{Si}}, \mathrm{Hz}$ & 122.9 & 98.8 & 119.7 & 106.9 \\
$\lambda_{\max }, \mathrm{nm}$ & 441 & 430 & 417 & 431 \\
$\varepsilon, 10^{3} \mathrm{M}^{-1} \mathrm{~cm}^{-1}$ & 8.3 & 9.6 & 10 & 10 \\
\hline
\end{tabular}

Single crystals of $\mathbf{2 a}$ were investigated by X-ray diffraction to confirm the structure deduced from the spectroscopic data (Figure 1). Stannyl disilene 2a crystallised with two independent molecules plus half a molecule of hexane in the asymmetric unit. Both molecules differ slightly in the $\mathrm{Si}=\mathrm{Si}$ bond length (2a: Si1-Si2: 216.18(8); Si3-Si4 217.18(9) pm). A similar observation had been made in case of $\mathrm{Tip}_{2} \mathrm{Si}=\mathrm{Si}$ (Tip) $\mathrm{SiPh}_{2} \mathrm{Cl}$, which exhibits four different $\mathrm{Si}=\mathrm{Si}$ bond lengths in the asymmetric unit.[6e] Similarly, in case of $\mathbf{2 a}$ the variability of the $\mathrm{Si}=\mathrm{Si}$ bond length can be rationalised with the conformational flexibility of the $\mathrm{Si}=\mathrm{Si}$ double bond: the relatively weak crystal packing forces account for a substantial variations in transbending of the disilene molecules, which in turn are closely related to the $\mathrm{Si}=\mathrm{Si}$ bond length. In case of $\mathbf{2 a}$ the smaller trans-bent angles $\theta$ are found in the molecule with the shorter $\mathrm{Si}=\mathrm{Si}$ distance $\left(\mathbf{2 a}: \theta_{\mathrm{Si} 1}=10.85^{\circ}, \theta_{\mathrm{Si} 2}=14.74^{\circ}, \theta_{\mathrm{Si} 3}=\right.$ $18.82^{\circ}, \theta_{\mathrm{Si} 4}=17.87^{\circ} ; \theta$ is the angle between the $\mathrm{Si}=\mathrm{Si}$ bond vector and the normal of the plane defined by a $\mathrm{Si}$ atom and the ipso atoms of the pendant groups). The Sn-Si distances of the two molecules of $\mathbf{2 a}$ are virtually identical (256.75(6) $\mathrm{pm}$ to $256.23(6) \mathrm{pm}$ ) and in the expected range for $\mathrm{Sn}-\mathrm{Si}$ single bonds from $252 \mathrm{pm}$ to $261 \mathrm{pm}$.[7]

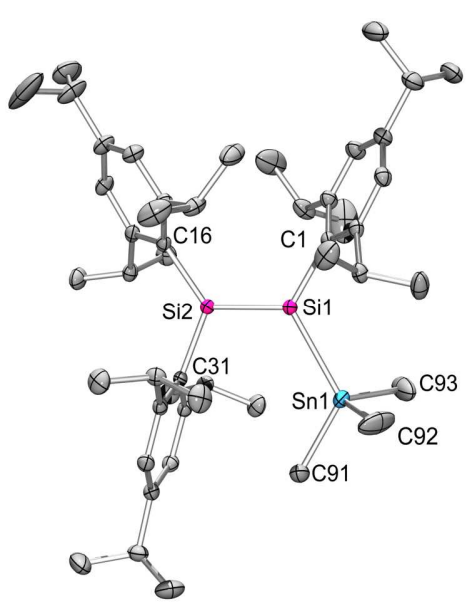

Figure 1. Structure of 2a in the solid state. Thermal ellipsoids at the $30 \%$ probability level. Only one of the two independent molecules shown. Disordered ${ }^{i} \operatorname{Pr}$ groups and protons omitted for clarity. Selected bond lengths $[\mathrm{pm}]$ and angles $\left[^{\circ}\right]$ (for the depicted molecule only): Si1-Si2 216.18(8), Si1-Sn1 256.75(6), Si1-C1 189.6(2), Si2-C16 190.9(2), Si2-C31 189.3(2), Si2-Si1-Sn1 120.57(3), Sn1-Si1-C1 117.79(7), C1-Si1-Si2 121.56(7), C16-Si2Si1 125.40(7), C16-Si2-C31 122.17(10), C31-Si2-Si1 111.69(7).

Like in the case of $\mathbf{2 a}$, the structure of chlorostannyl substituted disilene $\mathbf{3}$ in the solid state as determined by Xray diffraction on single crystals shows two independent molecules in the asymmetric unit (Figure 2). The $\mathrm{Si}=\mathrm{Si}$ bonds of $\mathbf{3}$ are slightly longer than those of $\mathbf{2 a}$ (3: Si1-Si2: 218.82(12) pm, Si3-Si4: 217.67(11) pm). The same holds true for the Sn-Si bonds (3: Si1-Sn1 259.74(9) pm, Si3-Sn2 258.97(9) pm), which suggests that all elongations relative to $\mathbf{2 a}$ are mainly due to the increased steric demand of the substitution pattern in $\mathbf{3}$ rather than to any $\sigma^{*}$-conjugative effects. Similarly as in $\mathbf{2 a}$ the shorter $\mathrm{Si}=\mathrm{Si}$ bond correlate to smaller trans-bent angles $\left(3: \theta_{\mathrm{Si} 1}=22.42^{\circ}, \theta_{\mathrm{Si} 2}=17.95^{\circ}, \theta_{\mathrm{Si} 3}\right.$ $=15.36^{\circ}, \theta_{\mathrm{Si} 4}=10.53^{\circ}$ ). It is noteworthy that the tin coordination environments are considerably distorted from the ideal tetrahedral one. The sums of bonds angles at the tin atoms disregarding the angles involving chlorine is close to $360^{\circ}$, which indicates an almost triangular pyramidal coordination sphere (Sn1 354.6 $\left.6^{\circ} \mathrm{Sn} 2351.7^{\circ}\right)$. The tinchlorine distance is inconspicuous (Sn1-Cl1 239.63(9) pm, $\mathrm{Sn} 2-\mathrm{Cl} 2240.70(10) \mathrm{pm})$ and therefore the described distortion could well be attributed to steric congestion. In fact, similar structural parameters at the tin atom have been reported for the simple monostannane $\operatorname{Mes} * \operatorname{Sn}(\mathrm{Cl})^{t} \mathrm{Bu}_{2}$ (Mes* $=2,4,6-{ }^{t} \mathrm{Bu}_{3} \mathrm{C}_{6} \mathrm{H}_{2}$ ). [8] Although not manifested in the observed intramolecular Sn1-Si2 distances (419.92(10) and 418.56(10) pm), a weak through space interaction and thus a certain degree of coordination sphere expansion of tin from 4 to 5 cannot be excluded.

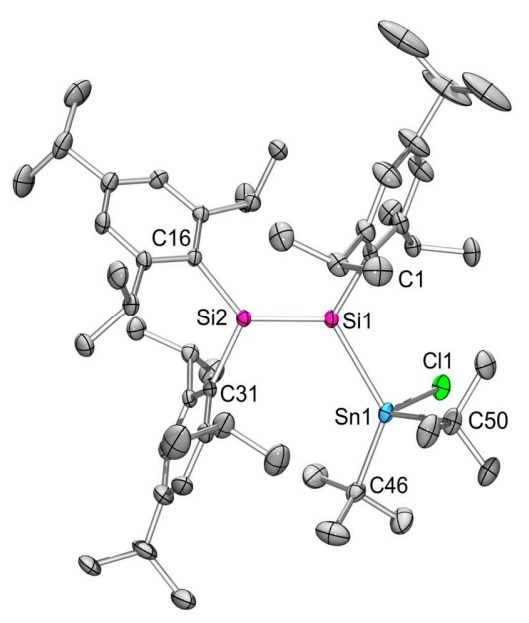

Figure 2. Structure of $\mathbf{3}$ in the solid state. Thermal ellipsoids at the $30 \%$ probability level. Only one of the two independent molecules shown. Co-crystallised hexane, disordered ${ }^{i} \mathrm{Pr}$ groups and protons omitted for clarity. Selected bond lengths [pm] and angles [ ${ }^{\circ}$ (for the depicted molecule only): Si1-Si2 218.82(12), Si1-Sn1 259.74(9), Si1-C1 189.8(3), Si2-C16 189.9(3), Si2-C31 188.6(3), Sn1-Cl1 239.63(9), Si2-Si1-Sn1 122.44(4), Sn1-Si1-C1 115.62(9), C1-Si1-Si2 117.86(10), C16-Si2-Si1 130.05(9), C16-Si2-C31 111.34(12), C31-Si2-Si1 115.39(9), Si1-Sn1-Cl1 99.91(3), Si1Sn1-C46 125.06(9), Si1-Sn1-C50 112.87(9).

At least in solution, the NMR spectroscopic analysis of $\mathbf{3}$ indeed suggests the presence of a through space interaction between $\mathrm{Sn} 1$ and $\mathrm{Si} 2$, the silicon atom in $\beta$-position to the stannyl group. The ${ }^{119} \mathrm{Sn}$ signal of $\mathbf{3}$ is considerably shifted to low field by the presence of the electronegative chlorine atom. Additionally, an electronegative substituent such as chlorine is expected to lower the $\sigma^{*}$ orbitals at tin and thus facilitate any through space interaction. Indeed, the chlorostannyl substituted disilene $\mathbf{3}$ exhibits a rather small one-bond coupling constant of ${ }^{1} \mathrm{~J}\left({ }^{119} \mathrm{Sn} /{ }^{29} \mathrm{Si}\right)=88.4 \mathrm{~Hz}$, which is in fact smaller than the two-bond coupling of 
${ }^{2} \mathrm{~J}\left({ }^{119} \mathrm{Sn} /{ }^{29} \mathrm{Si}\right)=106.9 \mathrm{~Hz}$. This would be nicely explained by a second coupling pathway with reversed sign attenuating the ${ }^{1} \mathrm{~J}$ coupling constant.

As mentioned before, however, no corroborating evidence for such an interaction could be obtained from neither spectroscopic nor crystallographic data. It is known that tin coupling constants are very sensitive to small variations in structural parameters even though there are only few examples of clear-cut correlations between ${ }^{1} \mathrm{~J}\left({ }^{119} \mathrm{Sn} /{ }^{13} \mathrm{C}\right)$ and ${ }^{2} \mathrm{~J}\left({ }^{119} \mathrm{Sn} /{ }^{1} \mathrm{H}\right)$ coupling constants and bond angles or distances.[9] Likewise the prediction of ${ }^{119} \mathrm{Sn}$-coupling constants by quantum chemical methods is still in its infancy and a matter of current research.[10]

In order to probe whether the steric demand of the tert.butyl groups at tin might prevent a more tangible 1,3interaction between $\mathrm{Sn} 1$ and $\mathrm{Si} 2$, we investigated the reaction of 1 with $\mathrm{Me}_{2} \mathrm{SnCl}_{2}$. The treatment of disilenide 1 with a 1.2 fold excess of $\mathrm{Me}_{2} \mathrm{SnCl}_{2}$ indeed results among other unidentified products in the formation of a threemembered ring compound (Scheme 1), albeit one where the chlorine atom has shifted from Sn1 to Si1 in what resembles the isomerisation of chlorosilyl substituted disilenes to cyclotrisilanes.[6e]

The first disilastannirane 4 was isolated in $21 \%$ yield by crystallisation at $0^{\circ} \mathrm{C}$ from hexane and characterised by multinuclear NMR spectroscopy and X-ray diffraction of a single crystal. The ${ }^{29} \mathrm{Si}$ NMR spectrum shows two signals at $-28.3 \mathrm{ppm}$ and $-57.3 \mathrm{ppm}$ in the typical region for heavier cyclopropanes.[11] The ${ }^{119} \mathrm{Sn}$ NMR signal is observed at $-252.4 \mathrm{ppm}$. Due to the relatively broad signals the tinsilicon coupling constants could not be resolved in case of 4 . Unlike the open-chained derivatives 2a-c and $\mathbf{3}$, cyclic $\mathbf{4}$ is sensitive to light. When a solution of $\mathbf{4}$ in benzene is exposed to ambient light, complete conversion to an as yet unidentified product is attained after one week.

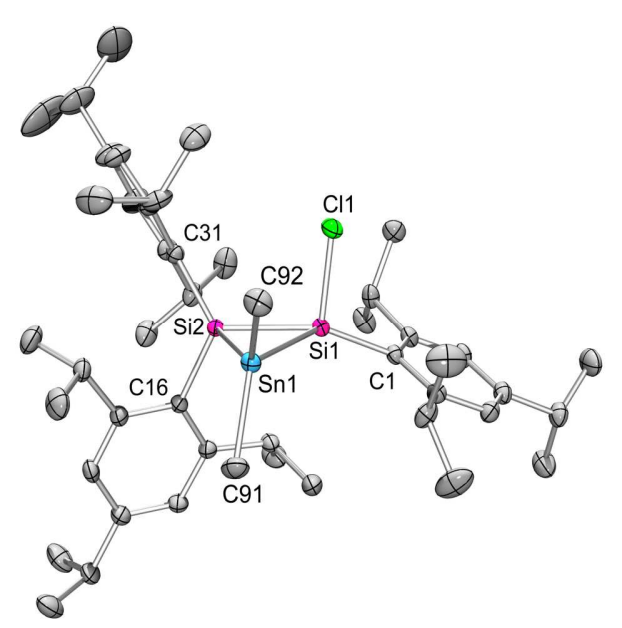

Figure 3. Structure of $\mathbf{4}$ in the solid state. Thermal ellipsoids at the $30 \%$ probability level. Only one of the two independent molecules is displayed and hydrogen atoms are omitted for clarity. Selected bond lengths $[\mathrm{pm}]$ and angles $\left[^{\circ}\right]$ (for the depicted molecule only): Si1-Si2 237.66(9), Si1-Sn1 254.22(6), Si2-Sn1 261.26(7), Si1-Cl1 210.45(9), Si1-C1 189.8(2), Si2-C16 190.5(2), Si2-C31 191.2(2), C1-Si1-Si2 141.59(7), C1-Si1-Sn1 135.91(8), Si2-Si1-Sn1 64.06(2), Si1-Si2-Sn1 61.05(2), Si1-Sn1-Si2 54.89(2), Si2-Si1Sn1-C91 97.33(10), Si2-Si1-Sn1-C91 -121.61(10).
Disilastannirane 4 crystallises with two independent molecules in the asymmetric unit (Figure 3). The Si-Si bond lengths are determined to 237.66(9) $\mathrm{pm}$ and 237.99(9) pm, which is significantly longer than the corresponding $\mathrm{Si}-\mathrm{Si}$ bond of the related cyclotrisilane $\mathbf{5}$ (235.8(1) pm). [6e] Given the unavailability of data on disilastannirane comparison with the known disilagermiranes seems appropriate. Derivative 6 was reported by Watanabe, Goto et al. in 1996,[12] 7 by Sekiguchi et al. in 2003 (Chart 1).[13]

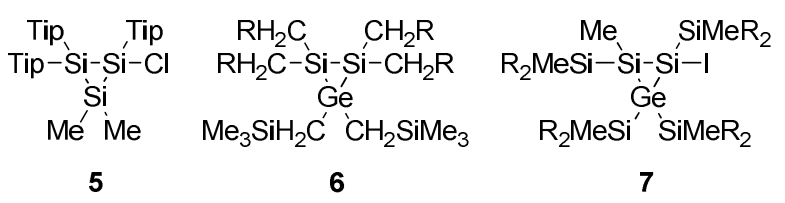

Chart 1. Heavy cyclopropane analogues 5,[6e] 6,[12] and 7 (Tip = 2,4,6- ${ }^{i} \mathrm{Pr}_{3} \mathrm{C}_{6} \mathrm{H}_{2}, \mathrm{R}={ }^{t} \mathrm{Bu}$ ).[13]

One of the $\mathrm{Si}-\mathrm{Si}-\mathrm{Sn}$ angles of each molecule of $\mathbf{4}$ is considerably wider than the other (Si2-Si1-Sn1 64.06(2) Si4-Si3-Sn2 63.67(2) ${ }^{\circ}$; Si1-Si2-Sn1 61.05(2) ${ }^{\circ}, \mathrm{Si3}-\mathrm{Si} 4-\mathrm{Sn} 2$ $\left.61.38(2)^{\circ}\right)$, which avoids the steric congestion around $\mathrm{Si} 2$ to some extent. In accord with the larger covalent radius, the endocyclic angle of 4 at tin (Si1-Sn1-Si2 54.89(2) ${ }^{\circ}$; Si3$\left.\mathrm{Sn} 2-\mathrm{Si} 454.94(2)^{\circ}\right)$ is significantly smaller than the corresponding angles of 6 and 7 at germanium $\left(6: 58.6^{\circ} ; 7\right.$ : $\left.57.19^{\circ}\right) .[12,13]$ The resulting higher ring strain should favour any ring opening or expansion reaction, which could explain the relatively high sensitivity of $\mathbf{4}$ towards light. Additionally, unlike the corresponding cyclotrisilane $\mathbf{5}$ the tin derivative $\mathbf{4}$ is sensitive towards oxygen and moisture. This increased reactivity of $\mathbf{4}$ might well be of preparative use in future studies.

\section{Conclusion}

The first stannyl substituted disilenes 2a-c were synthesised from disilenide $\mathbf{1}$ and the appropriate chlorostannanes. While the reaction of $\mathbf{1}$ and ${ }^{t} \mathrm{Bu}_{2} \mathrm{SnCl}_{2}$ yields $S n$-functional stannyl disilene $\mathbf{3}$, treatment of $\mathbf{1}$ with $\mathrm{Me}_{2} \mathrm{SnCl}_{2}$ affords the first disilastannirane 4. All new compounds were characterised by multinuclear NMR spectroscopy and the derived structures were confirmed by single crystal X-ray diffraction for each class of compounds. Studies concerning the reactivity of stannyl disilenes 2a-c are currently in progress.

\section{Experimental Section}

All manipulations were carried out under a protective atmosphere of argon or nitrogen using standard Schlenk techniques and a glovebox. Ethereal solvents were refluxed over sodium/benzophenone; hexane over sodium and deuterated benzene over potassium. All solvents were stored under argon and degassed prior to use. NMR spectra were recorded on a Bruker DRX400 NMR spectrometer $\left({ }^{119} \mathrm{Sn}, 149.21 \mathrm{MHz}\right)$ FT-NMR spectrometer or a Bruker Avance 500 NMR spectrometer $\left({ }^{1} \mathrm{H}\right.$, $500.13 \mathrm{MHz},{ }^{13} \mathrm{C}, 125.76 \mathrm{MHz},{ }^{29} \mathrm{Si}$, 99.36 MHz) FT-NMR spectrometer. ${ }^{1} \mathrm{H}$ and ${ }^{13} \mathrm{C}\left\{{ }^{1} \mathrm{H}\right\}$ NMR spectra were referenced to the peaks of residual protons of deuterated solvents $\left({ }^{1} \mathrm{H}\right)$ or the deuterated solvent itself $\left({ }^{13} \mathrm{C}\right) .{ }^{29} \mathrm{Si}$ NMR spectra were referenced 
to external TMS and ${ }^{119} \mathrm{Sn}$ NMR spectra were referenced to external $\mathrm{Bu}_{4} \mathrm{Sn}$ in $\mathrm{C}_{6} \mathrm{D}_{6}(-11.7 \mathrm{ppm})$. All chemical shifts are reported in ppm. Elemental analyses $(\mathrm{C}, \mathrm{H})$ were performed on a Leco Instruments Elemental Analyzer, type CHNS 932. UV-Vis spectra were recorded on a Perkin Elmer Lambda $20 \mathrm{UV} / \mathrm{V}$ is Spectrometer. Melting points were determined under argon or nitrogen in closed NMR tubes and are uncorrected. $\mathrm{Tip}_{2} \mathrm{Si}=\mathrm{Si}(\mathrm{Tip}) \mathrm{Li}$ (1) was prepared according to our published procedure.[5a] Chlorostannanes were purchased from SigmaAldrich and used as received.

\section{1-Trimethylstannyl-1,2,2-tris(2',4',6'-triisopropylphenyl)-}

disilene (2a): Via cannula $40 \mathrm{~mL}$ of hexane are added to a mixture of $1.69 \mathrm{~g}(1.980 \mathrm{mmol})$ disilenide $\mathbf{1}$ and $0.39 \mathrm{~g}(1.957 \mathrm{mmol})$ $\mathrm{Me}_{3} \mathrm{SnCl}$. The resulting orange suspension is stirred overnight at r.t. Precipitated solids are filtered off and solvents are evaporated to yield a red oil. After a few days $1.56 \mathrm{~g}(95 \%) \mathbf{2 a}$ are obtained as red crystals (mp. $141{ }^{\circ} \mathrm{C}$, dec) from a minimum amount of pentane. ${ }^{1}$ H NMR $\left(500 \mathrm{MHz}, \mathrm{C}_{6} \mathrm{D}_{6}\right.$, r.t.): $\delta=7.10,7.08,7.01$ (each s, each $2 \mathrm{H}$, Tip- $H$ ), 4.35, 4.10, 3.90 (each hept., each $2 \mathrm{H}, \mathrm{iPr}-\mathrm{CH}$ ), 2.82 (m, 2H, iPr-CH), 2.72 (hept., $1 \mathrm{H}, \mathrm{iPr}-\mathrm{C} H$ ) , 1.33, 1.26, 1.24, 1.14, 0.99 (each d, altogether 54H, iPr- $\left.\mathrm{CH}_{3}\right), 0.19\left(\mathrm{Sn}_{-} \mathrm{CH}_{3}\right) .{ }^{13} \mathbf{C}$ NMR $\left(125 \mathrm{MHz}, \mathrm{C}_{6} \mathrm{D}_{6}\right.$, r.t.): $\delta=155.96,155.38,155.15$ (Tip- $\left.C_{\mathrm{o}}\right)$, $151.32,150.92,150.15$ (Tip- $C_{\mathrm{i}}$ ), $135.14,134.61,132.18$ (Tip- $C_{\mathrm{p}}$ ), 122.24, 122.01, 121.56 (Tip- $\mathrm{CH}$ ), 38.41, 37.53, 36.39, 34.94, 34.88, 34.54 (iPr-CH), 25.16 (br.), 24.68, 24.29, 24.26, $24.03\left({ }^{i} \mathrm{Pr}-\right.$ $\left.\mathrm{CH}_{3}\right),-5.17\left({ }^{1} \mathrm{~J}(\mathrm{Sn}, \mathrm{C})=283.7 \mathrm{~Hz}, \mathrm{Sn}-\mathrm{CH}_{3}\right) .{ }^{29} \mathrm{Si}$ NMR $(99.36$ $\mathrm{MHz}, \mathrm{C}_{6} \mathrm{D}_{6}$, r.t. $): \delta=103.4\left({ }^{2} \mathrm{~J}(\mathrm{Sn}, \mathrm{Si})=122.9 \mathrm{~Hz}, \mathrm{SiTip}_{2}\right), 38.9$ $\left({ }^{1} \mathrm{~J}(\mathrm{Sn}, \mathrm{Si})=474.2 \mathrm{~Hz}, \mathrm{SiTip}\right) .{ }^{119} \mathrm{Sn}$ NMR $\left(186.46 \mathrm{MHz}, \mathrm{C}_{6} \mathrm{D}_{6}\right.$, r.t. $): \delta=-68.3\left({ }^{1} \mathrm{~J}(\mathrm{Sn}, \mathrm{Si})=474.2 \mathrm{~Hz},{ }^{2} \mathrm{~J}(\mathrm{Sn}, \mathrm{Si})=122.9 \mathrm{~Hz}\right.$, und $\left.{ }^{1} \mathrm{~J}(\mathrm{Sn}, \mathrm{C})=283.7 \mathrm{~Hz}, S n \mathrm{Me}_{3}\right)$. UV/Vis (hexane): $\lambda_{\max }(\varepsilon) 441 \mathrm{~nm}$ (8300 $\mathrm{Lmol}^{-1} \mathrm{~cm}^{-1}$ ). Element. anal.: Calcd. for $\mathrm{C}_{48} \mathrm{H}_{78} \mathrm{Si} \mathrm{i}_{2} \mathrm{Sn}$ : $\mathrm{C}$, 69.46; H, 9.47. Found: C, 68.70; H, 9.37. Exact Mass (ESI-MS) Calcd. $m / z$ for $\mathrm{C}_{48} \mathrm{H}_{78} \mathrm{Si}_{2} \mathrm{Sn}^{+}\left(\mathrm{M}^{+}\right)$: 830.4664. Found: 830.4662. MS $(\mathrm{CI}$, isobutane $) \mathrm{m} / z=830\left(\mathrm{M}^{+}\right), 697\left(\mathrm{M}^{+}+\mathrm{O}_{2}-\mathrm{SnMe}_{3}\right), 665$ $\left(\mathrm{M}^{+}-\mathrm{SnMe}_{3}\right), 449\left(\mathrm{Tip}_{2} \mathrm{SiMe}^{+}\right), 433,321,261,245,231,203,189$, $43\left(\mathrm{C}_{3} \mathrm{H}_{7}^{+}\right)$.

1-Tributylstannyl-1,2,2-tris(2',4',6'-triisopropylphenyl)disilene (2b): Via cannula $30 \mathrm{~mL}$ of toluene are added to $5.14 \mathrm{~g}(6.023$ mmol) disilenide 1 . The orange solution is cooled to $0{ }^{\circ} \mathrm{C}$ and 1.96 $\mathrm{g}(6.021 \mathrm{mmol}) \mathrm{Bu}_{3} \mathrm{SnCl}$ are added via syringe. After stirring for $16 \mathrm{~h}$ the precipitated $\mathrm{LiCl}$ is removed by filtration. All volatiles are removed in vacuum and the solid residue is dissolved in approx. 5 $\mathrm{mL}$ of pentane. After 5 days at $0{ }^{\circ} \mathrm{C} 4.97 \mathrm{~g}(86 \%) \mathbf{2 b}$ are separated from the mother liquor as red crystals (mp. $64-67{ }^{\circ} \mathrm{C}$ ).

${ }^{1}$ H NMR (500 MHz, $\mathrm{C}_{6} \mathrm{D}_{6}$, r.t.): $\delta=7.072,7.070,6.99$ (each s, each $2 \mathrm{H}$, Tip- $H$ ) , 4.36, 4.12, 3.86 (each hept., each $2 \mathrm{H}, \mathrm{iPr}-\mathrm{CH}$ ), 2.79, 2.75, 2.66 (each hept., each $1 \mathrm{H}, \mathrm{iPr}-\mathrm{CH}), 1.57(\mathrm{~m}, 6 \mathrm{H}, \mathrm{Bu}-$ $\left.\mathrm{C}_{\gamma} \mathrm{H}_{2}\right), 1.38\left(\mathrm{~d}, 12 \mathrm{H}, \mathrm{iPr}-\mathrm{CH}_{3}\right), 1.32\left(\mathrm{q}, 6 \mathrm{H}, \mathrm{Bu}-\mathrm{C}_{\alpha} \mathrm{H}_{2}\right), 1.24,1.19$, 1.10 (each d, altogether $36 \mathrm{H}$, $i \mathrm{Pr}-\mathrm{CH}_{3}$ ), $0.98\left(\mathrm{~m}, 6 \mathrm{H}, \mathrm{Bu}-\mathrm{C}_{\beta} \mathrm{H}_{2}\right.$ ), $0.96\left(\mathrm{~d}, 6 \mathrm{H}, \mathrm{iPr}-\mathrm{CH}_{3}\right), 0.88\left(\mathrm{t}, 9 \mathrm{H}, \mathrm{Bu}-\mathrm{C}_{\delta} H_{3}\right) .{ }^{13} \mathbf{C}$ NMR $(125 \mathrm{MHz}$, $\mathrm{C}_{6} \mathrm{D}_{6}$, r.t.): $\delta=155.84,155.24,154.99$ (Tip- $\left.C_{\mathrm{o}}\right), 151.13,150.85$, 150.13 (Tip- $C_{\mathrm{p}}$ ), 135.65, 135.47, 132.92 (Tip- $\left.C_{\mathrm{i}}\right), 122.33,121.97$, 121.66 (Tip-CH), 38.34, 37.41, 36.54, 34.84, 34.77, 34.49 (iPr$C \mathrm{H}), 30.45,27.94\left({ }^{1} \mathrm{~J}(\mathrm{Sn}, \mathrm{C})=63.4 \mathrm{~Hz}, \mathrm{Bu}-C_{\gamma / \alpha}\right), 24.60,24.17$, $23.94\left(\mathrm{iPr}-\mathrm{CH}_{3}\right), 13.98,12.44\left({ }^{2} \mathrm{~J}(\mathrm{Sn}, \mathrm{C})=280.1 \mathrm{~Hz}, \mathrm{Bu}-C_{\delta / \beta}\right)$. ${ }^{29} \mathrm{Si} \mathrm{NMR}\left(99.36 \mathrm{MHz}, \mathrm{C}_{6} \mathrm{D}_{6}\right.$, r.t.): $\delta=105.3\left({ }^{2} \mathrm{~J}(\mathrm{Sn}, \mathrm{Si})=98.8 \mathrm{~Hz}\right.$, $\left.\mathrm{SiTip}_{2}\right), 36.8\left({ }^{1} \mathrm{~J}(\mathrm{Sn}, \mathrm{Si})=353.6 \mathrm{~Hz}\right.$, SiTip) ppm. ${ }^{{ }^{119}} \mathrm{Sn}$ NMR $\left(186.46 \mathrm{MHz}, \mathrm{C}_{6} \mathrm{D}_{6}\right.$, r.t. $): \delta=-52.9\left({ }^{1} \mathrm{~J}(\mathrm{Sn}, \mathrm{Si})=353.6 \mathrm{~Hz}\right.$, ${ }^{2} \mathrm{~J}(\mathrm{Sn}, \mathrm{Si})=98.8 \mathrm{~Hz},{ }^{2} \mathrm{~J}(\mathrm{Sn}, \mathrm{C})=280.1 \mathrm{~Hz}$ und ${ }^{1} \mathrm{~J}(\mathrm{Sn}, \mathrm{C})=63.4 \mathrm{~Hz}$, $\mathrm{SnBu}_{3}$ ). UV/Vis (hexane): $\lambda_{\max }(\varepsilon) 430 \mathrm{~nm}\left(9620 \mathrm{Lmol}^{-1} \mathrm{~cm}^{-1}\right)$.
Element. anal.: Calcd. for $\mathrm{C}_{57} \mathrm{H}_{96} \mathrm{Si}_{2} \mathrm{Sn}$ : $\mathrm{C}, 71.59 ; \mathrm{H}, 10.12$. Found: C, 71.55; H, 9.96. MS (CI, isobutane) $m / z=956\left(\mathbf{M}^{+}\right), 931$ $\left(\mathrm{M}^{+}+\mathrm{O}_{2}-\mathrm{C}_{4} \mathrm{H}_{9}\right), \quad 899 \quad\left(\mathrm{M}^{+}-\mathrm{C}_{4} \mathrm{H}_{9}\right), 697 \quad\left(\mathrm{M}^{+}+\mathrm{O}_{2}-\mathrm{SnBu}_{3}\right), 665$ $\left(\mathrm{M}^{+}-\mathrm{SnBu}_{3}\right), 491\left(\mathrm{Tip}_{2} \mathrm{SiBu}^{+}\right), 433,345,323\left(\mathrm{SnBu}_{3}{ }^{+}+\mathrm{O}_{2}\right), 289$, 231, 203, 189, $43\left(\mathrm{C}_{3} \mathrm{H}_{7}^{+}\right)$.

\section{1-Triphenylstannyl-1,2,2-tris(2',4',6'-triisopropylphenyl)-} disilene (2c): Via cannula $25 \mathrm{~mL}$ of toluene are added to a mixture of $2.54 \mathrm{~g}$ (2.976 mmol) disilenide 1 and $1.15 \mathrm{~g}$ (2.983 mmol) $\mathrm{Ph}_{3} \mathrm{SnCl}$ at $0{ }^{\circ} \mathrm{C}$. The resulting orange suspension is stirred overnight at r.t. Precipitated solids are filtered off and volatiles are removed from the filtrate in vacuum. The remaining solid is dissolved in $5 \mathrm{~mL}$ of hot hexane. After $16 \mathrm{~h}$ at r.t. $2.21 \mathrm{~g}(73 \%) \mathbf{2 c}$ are isolated as red crystals $\left(\mathrm{mp} .170{ }^{\circ} \mathrm{C}, \mathrm{dec}\right)$.

${ }^{1} \mathbf{H}$ NMR $\left(500 \mathrm{MHz}, \mathrm{C}_{6} \mathrm{D}_{6}\right.$, r.t.): $\delta=7.74-7.60$ (m, 6H, Ph- $H$ ), 7.09-7.03 (m, 9H, Ph- $H$ ), 7.02, 6.99, 6.91 (each s, each 2H, Tip- $H$ ), 4.42, 4.06, 3.88 (each hept., each $2 \mathrm{H}$, iPr- $\mathrm{CH}$ ), 2.68 (m, 3H, iPr$\mathrm{CH}$ ), 1.25 (br., 6H, iPr-CH ), 1.144, 1.137, 1.12 (each d, each 6H, iPr- $\mathrm{CH}_{3}$ ) , 1.05, 0.98 (each d, each $\left.12 \mathrm{H}, \mathrm{iPr}-\mathrm{CH}_{3}\right) .{ }^{13} \mathbf{C}$ NMR $(125$ $\mathrm{MHz}, \mathrm{C}_{6} \mathrm{D}_{6}$, r.t.): $\delta=155.96,155.13,154.56$ (Tip- $C_{\mathrm{o}}$ ), 151.25 , $151.09,150.77\left(\right.$ Tip- $\left.C_{\mathrm{p}}\right), 142.35\left({ }^{1} \mathrm{~J}(\mathrm{Sn}, \mathrm{C})=434.5 \mathrm{~Hz}, \mathrm{Ph}-C_{\mathrm{i}}\right)$, $137.85\left({ }^{2} \mathrm{~J}(\mathrm{Sn}, \mathrm{C})=40.8 \mathrm{~Hz}, \mathrm{Ph}-C_{\mathrm{o}}\right), 135.71,134.34,130.97$ (Tip$\left.C_{\mathrm{i}}\right), 128.59\left(\mathrm{Ph}-C_{\mathrm{m} / \mathrm{p}}\right), 122.51,122.31,122.00$ (Tip- $\left.C \mathrm{H}\right), 38.15$, 38.04, 37.54, 34.77, 34.58, 34.50 (iPr- $\mathrm{CH}), 24.86,24.55,24.10$, 24.04, 23.96 (iPr- $\left.\mathrm{CH}_{3}\right) .{ }^{29} \mathrm{Si}$ NMR (99.36 MHz, $\mathrm{C}_{6} \mathrm{D}_{6}$, r.t.): $\delta=$ $113.3\left({ }^{2} \mathrm{~J}(\mathrm{Sn}, \mathrm{Si})=119.7 \mathrm{~Hz}, \mathrm{SiTip}_{2}\right), 30.4\left({ }^{1} \mathrm{~J}(\mathrm{Sn}, \mathrm{Si})=480.7 \mathrm{~Hz}\right.$, SiTip) ppm. ${ }^{119}$ Sn NMR (186.46 MHz, $\mathrm{C}_{6} \mathrm{D}_{6}$, r.t.): $\delta=-108.9$ $\left({ }^{1} \mathrm{~J}(\mathrm{Sn}, \mathrm{Si})=480.7 \mathrm{~Hz},{ }^{2} \mathrm{~J}(\mathrm{Sn}, \mathrm{Si})=119.7 \mathrm{~Hz},{ }^{1} \mathrm{~J}(\mathrm{Sn}, \mathrm{C})=434.5 \mathrm{~Hz}\right.$ und $\left.{ }^{2} \mathrm{~J}(\mathrm{Sn}, \mathrm{C})=40.8 \mathrm{~Hz}, \mathrm{SnPh}_{3}\right)$. UV/Vis (hexane): $\lambda_{\max }(\varepsilon) 417 \mathrm{~nm}$ (10050 $\mathrm{Lmol}^{-1} \mathrm{~cm}^{-1}$ ). Element. anal.: Calcd. for $\mathrm{C}_{63} \mathrm{H}_{84} \mathrm{Si}_{2} \mathrm{Sn}$ : C, 74.46; H, 8.33. Found: C, 74.00; H, 8.36. MS (CI, isobutane) $\mathrm{m} / \mathrm{z}=$ $1048\left(\mathrm{M}^{+}+\mathrm{O}_{2}\right), 1016\left(\mathrm{M}^{+}\right), 971\left(\mathrm{M}^{+}+\mathrm{O}_{2}-\mathrm{C}_{6} \mathrm{H}_{5}\right), 767$ (11), 742 $\left(\mathrm{M}^{+}-\mathrm{SnPh}_{2}\right), 697\left(\mathrm{M}^{+}+\mathrm{O}_{2}-\mathrm{SnPh}_{3}\right), 511\left(\mathrm{Tip}_{2} \mathrm{SiPh}^{+}\right), 494,433,351$ $\left(\mathrm{SnPh}_{3}{ }^{+}\right), 273,231,204,189,43\left(\mathrm{C}_{3} \mathrm{H}_{7}^{+}\right)$.

1-(Chlorodi-tert. -butylstannyl)-1,2,2-tris(2',4',6'-

triisopropylphenyl)disilene (3): Via cannula $25 \mathrm{~mL}$ of hexane are added to a mixture of $1.40 \mathrm{~g}$ ( $1.640 \mathrm{mmol})$ disilenide 1 and $0.50 \mathrm{~g}$ (1.646 mmol) ${ }^{t} \mathrm{Bu}_{2} \mathrm{SnCl}_{2}$ at r.t. The colour of the mixture turns to dark red. After stirring overnight, all insoluble parts are removed by filtration. The filtrate is reduced until the product starts to precipitate, which is re-dissolved by gentle heating to $35^{\circ} \mathrm{C}$. After keeping at r.t. overnight $0.91 \mathrm{~g}(59 \%) 3$ are obtained as deep red crystals (mp. $155^{\circ} \mathrm{C} \mathrm{dec}$.).

${ }^{1}$ H NMR (500 MHz, $\mathrm{C}_{6} \mathrm{D}_{6}$, r.t.): $\delta=7.07,7.03,6.98$ (each s, each $2 \mathrm{H}$, Tip- $H$ ), 4.39, 3.97, 3.65 (each hept., each $2 \mathrm{H}, \mathrm{iPr}-\mathrm{CH}$ ), 2.72 (m, 2H, iPr-CH), 2.63 (hept., $1 \mathrm{H}, \mathrm{iPr}-\mathrm{CH}), 1.43$ (d, 12H, iPr-CH $\mathrm{CH}_{3}$, $1.27\left(\mathrm{~s}, 18 \mathrm{H}, \mathrm{tBu}-\mathrm{CH}_{3}\right), 1.18,1.14,1.07,0.92$ (each d, altogether $\left.42 \mathrm{H}, \mathrm{iPr}-\mathrm{CH}_{3}\right) .{ }^{13} \mathbf{C}$ NMR (125 MHz, $\mathrm{C}_{6} \mathrm{D}_{6}$, r.t.): $\delta=156.36$, 155.17, 155.06 (Tip- $C_{\mathrm{o}}$ ), 151.77, 151.24, 150.78 (Tip- $\left.C_{\mathrm{i}}\right), 135.27$, 134.88, 132.80 (Tip- $C_{\mathrm{p}}$ ), 122.81, $122.38,122.32$ (Tip- $\left.C \mathrm{H}\right), 40.88$ $\left({ }^{1} \mathrm{~J}(\mathrm{Sn}, \mathrm{C})=302.1 \mathrm{~Hz}, \mathrm{tBu}-\mathrm{CMe}_{3}\right), 38.47,38.02,36.85,34.85$, 34.72, 34.38 (iPr- $\mathrm{CH}$ ), 31.82 (tBu- $\mathrm{CH}_{3}$ ), 25.69 (br.), 24.70, 24.19, 24.02, $23.86\left(\mathrm{iPr}-\mathrm{CH}_{3}\right) .{ }^{29} \mathrm{Si}$ NMR (99.36 MHz, $\mathrm{C}_{6} \mathrm{D}_{6}$, r.t.): $\delta=114.5\left({ }^{2} \mathrm{~J}(\mathrm{Sn}, \mathrm{Si})=106.9 \mathrm{~Hz}, \mathrm{SiTip}_{2}\right), 40.9\left({ }^{1} \mathrm{~J}(\mathrm{Sn}, \mathrm{Si})=88.4 \mathrm{~Hz}\right.$, SiTip). ${ }^{119}$ Sn NMR (186.46 MHz, $\mathrm{C}_{6} \mathrm{D}_{6}$, r.t.): $\delta=109.5$. UV/Vis (hexane): $\lambda_{\max }(\varepsilon) 431 \mathrm{~nm}\left(10000 \mathrm{Lmol}^{-1} \mathrm{~cm}^{-1}\right)$. Element. anal.: Calcd for $\mathrm{C}_{53} \mathrm{H}_{87} \mathrm{Si}_{2} \mathrm{SnCl}$ : C, 68.11; H, 9.38. Found: C, 67.22; H, 9.30. MS (CI, isobutane) $\mathrm{m} / z=935\left(\mathbf{M}^{+}\right), 909\left(\mathrm{M}^{+}+\mathrm{O}_{2}-\mathrm{C}_{4} \mathrm{H}_{9}\right), 877$ $\left(\mathrm{M}^{+}-\mathrm{C}_{4} \mathrm{H}_{9}\right), 853,671,665\left(\mathrm{M}^{+}-{ }^{t} \mathrm{Bu}_{2} \mathrm{SnCl}\right), 469\left(\mathrm{Tip}_{2} \mathrm{SiCl}^{+}\right), 435$, 265, 230, 204, 189, $57\left(\mathrm{C}_{4} \mathrm{H}_{9}^{+}\right), 43\left(\mathrm{C}_{3} \mathrm{H}_{7}^{+}\right)$. 
1,1-Dimethyl-2-chloro-2,3,3-tris(2',4',6'-triisopropylphenyl)disilastannirane (4): At r.t. a solution of $2.04 \mathrm{~g}(2.390 \mathrm{mmol})$ disilenide $\mathbf{1}$ in $20 \mathrm{~mL}$ of toluene is added dropwise to a solution of $0.85 \mathrm{~g}$ (3.869 mmol) $\mathrm{Me}_{2} \mathrm{SnCl}_{2}$ over a period of $15 \mathrm{~min}$. The resulting orange suspension is stirred overnight at r.t. All precipitates are filtered off and the filtrate is distilled off to give $2.25 \mathrm{~g}$ of a yellow solid. Crystallisation from $10 \mathrm{~mL}$ of hexane at $0^{\circ} \mathrm{C}$ yields $0.43 \mathrm{~g}(21 \%)$ of $\mathbf{4}$ as colourless blocks (mp. $168{ }^{\circ} \mathrm{C}$, dec).

${ }^{1}$ H NMR (500 MHz, toluene-d ${ }_{8}$, r.t.): $\delta=7.10,7.09,7.07$ (each s, each 1H, Tip- $H$ ), 6.92 (s, 2H, Tip- $H$ ), 6.86 (s, 1H, Tip- $H$ ), 4.45 4.32 (m, 2H, iPr-CH), 3.86 (hept., $1 \mathrm{H}, \mathrm{iPr}-\mathrm{CH}), 3.60,3.51,3.18$ (each br., each $1 \mathrm{H}, \mathrm{iPr}-\mathrm{CH}), 2.71(\mathrm{~m}, 2 \mathrm{H}, \mathrm{iPr}-\mathrm{CH}), 2.63$ (hept., $1 \mathrm{H}$, iPr-CH), 1.42 (d, 6H, iPr-CH $_{3}, 1.33$ (br., 3H, iPr- $\mathrm{CH}_{3}$ ), 1.30, 1.27, $1.17,1,16,1.14,1.13,1.082,1.077$ (each d, altogether 36H, iPr$\mathrm{CH}_{3}$ ), $0.81\left(\mathrm{Sn}-\mathrm{CH}_{3}\right), 0.64,0.44$ (each br., altogether $9 \mathrm{H}$, iPr- $\mathrm{CH}_{3}$ ), $0.16\left(\mathrm{Sn}-\mathrm{CH}_{3}\right) .{ }^{13} \mathbf{C}$ NMR $(125 \mathrm{MHz}$, toluene-d 8, r.t.): $\delta=156.25$, $156.18,156.06,156.01,153.91$ (Tip- $\left.C_{\mathrm{o}}\right), 152.08,150.80,150.31$ (Tip- $C_{\mathrm{i}}$ ), 133.37, 130.42, 130.01 (Tip- $C_{\mathrm{p}}$ ), 122.66, 122.12, 121.97, 121.71, 121.27, 121.23 (Tip- $\mathrm{CH}$ ), 38.17, 37.29, 37.14, 36.00, $35.68,34.87,34.66,34.53,34.29$ (iPr- $\mathrm{CH}$ ), 28.49 (br.), 27.94, $27.45,27.11,26.23,24.59,24.38,24.05,23.99,23.62,23.00,22.45$ $\left(\mathrm{iPr}-\mathrm{CH}_{3}\right),-8.72,-10.81\left(\mathrm{Sn}-\mathrm{CH}_{3}\right) .{ }^{29} \mathrm{Si}$ NMR $(99.36 \mathrm{MHz}$, toluene-d ${ }_{8}$, r.t.): $\delta=-28.3,-57.3 .{ }^{119} \mathrm{Sn}$ NMR $(186.46 \mathrm{MHz}$, toluene-d ${ }_{8}$, r.t.): $\delta=-252.4$. Exact Mass (ESI-MS) Calcd. $\mathrm{m} / \mathrm{z}$, for $\mathrm{C}_{47} \mathrm{H}_{75} \mathrm{Si}_{2} \mathrm{SnCl}^{+}\left(\mathrm{M}^{+}\right)$: 850.4118. Found: 850.4121. MS (CI, isobutane) $\mathrm{m} / z=850\left(\mathrm{M}^{+}\right), 665\left(\mathrm{M}^{+}-\mathrm{Me}_{2} \mathrm{SnCl}\right), 469\left(\mathrm{Tip}_{2} \mathrm{SiCl}^{+}\right)$, $449\left(\mathrm{Tip}_{2} \mathrm{SiMe}^{+}\right), 435,323,265,245,231,204,189,57,43$ $\left(\mathrm{C}_{3} \mathrm{H}_{7}^{+}\right)$.

Crystallography: Single crystals of $\mathbf{2 a}, \mathbf{3}$, and $\mathbf{4}$ were coated with perfluorinated polyether and quickly transferred to the cold nitrogen stream at the goniometer. The accumulation of data sets was carried out using a Bruker SMART CCD area-detector diffractometer with $\mathrm{Mo}-\mathrm{K}_{\alpha}$ radiation $(\lambda=0.71073 \AA$ ).[14] Unit cells were determined using a number of representative frames. Intensities were determined from several series of frames, each covering $0.3^{\circ}$ in $\omega$ of an entire sphere. Numerical absorption corrections were applied using SADABS. The structures were solved by direct methods or with a Patterson map and refined by least squares on weighted $F^{2}$ values for all reflections. Refinements (ShelXL-97) yielded the crystallographic parameters summarized in Table 2. Crystallographic data (excluding structure factors) for the structural analyses of $\mathbf{2 a}, \mathbf{3}$, and $\mathbf{4}$ have been deposited with the Cambridge Crystallographic Data Centre as CCDC-728277 to 728279 Copies of this information may be obtained free of charge from CCDC, 12 Union Road, Cambridge CB2 1EZ, UK (Fax: +441223-336033; E-Mail: deposit@ccdc.cam.ac.uk) or under http://www.ccdc.cam.ac.uk

Table 2. Selected Crystallographic Details for Compounds 2a, 3, and 4.

\begin{tabular}{llll}
\hline & $\mathbf{2 a}$ & $\mathbf{3}$ & $\mathbf{4}$ \\
\hline Formula & $\mathrm{C}_{99} \mathrm{H}_{163} \mathrm{Si}_{4} \mathrm{Sn}_{2}$ & $\mathrm{C}_{53} \mathrm{H}_{87} \mathrm{ClSi}_{2} \mathrm{Sn}$ & $\mathrm{C}_{47} \mathrm{H}_{75} \mathrm{ClSi}_{2} \mathrm{Sn}$ \\
$T, \mathrm{~K}$ & $173(2)$ & $173(2)$ & $173(2)$ \\
System & triclinic & orthorhombic & triclinic \\
Space group & $\mathrm{P}^{-} 1$ & $\mathrm{Pca} 2(1)$ & $\mathrm{P}^{-} 1$ \\
$a, \AA$ & $11.5193(6)$ & $22.389(5)$ & $14.1341(9)$ \\
$b, \AA$ & $17.6904(10)$ & $19.011(4)$ & $17.9108(11)$ \\
$c, \AA$ & $25.5702(14)$ & $25.944(5)$ & $20.6439(13)$ \\
$\alpha$ & $96.7910(10)^{\circ}$ & $90^{\circ}$ & $69.9390(10)^{\circ}$ \\
$\beta$ & $101.0180(10)^{\circ}$ & $90^{\circ}$ & $77.0990(10)^{\circ}$
\end{tabular}

$\begin{array}{llll}\gamma & 92.0510(10)^{\circ} & 90^{\circ} & 89.8660(10)^{\circ} \\ V, \AA^{3} & 5069.7(5) & 11043(4) & 4769.3(5) \\ Z & 2 & 8 & 4 \\ d, \mathrm{~g} \mathrm{~cm}^{-3} & 1.116 & 1.124 & 1.184 \\ \mu, \mathrm{mm}^{-1} & 0.580 & 0.585 & 0.671 \\ F(000) & 1826 & 4000 & 1808 \\ \theta_{\max } & 26.08^{\circ} & 26.02^{\circ} & 26.37^{\circ} \\ \operatorname{Refl}_{\text {total }} & 73180 & 92746 & 85064 \\ \operatorname{Refl}_{\text {.unique }} & 20064 & 21703 & 19517 \\ S & 1.063 & 1.066 & 1.026 \\ R_{I}(\mathrm{I}>2 \sigma) & 0.0393 & 0.0344 & 0.0353 \\ w R_{2}(\text { all } & 0.1080 & 0.0827 & 0.0898 \\ \mathrm{dat}) & & & \end{array}$

\section{Acknowledgments}

Financial support by the Deutsche Forschungsgemeinschaft (DFG SCHE906/3-2), the Aventis Foundation (Karl-Winnacker Fellowship), Imperial College London (start-up funds) is gratefully acknowledged. The authors thank Prof. Holger Braunschweig and his group for their continuous support, as well as Dr. R. Bertermann (University of Würzburg), Richard N. Sheppard and Dr. Peter R. Haycock (Imperial College London) for recording the NMR spectra.

[1] Reviews: a) J. K. Stille, Pure Appl. Chem. 1985, 57, 17711780; b) J. K. Stille, Angew. Chem. 1986, 98, 504-519; Angew. Chem. Int. Ed. Engl. 1986, 25, 508-524.

[2] D. Seyferth, M. A. Weiner, J. Am. Chem. Soc. 1961, 83, 3583-3586.

[3] D. Seyferth, M. A. Weiner, J. Org. Chem. 1961, 26, 47974800 .

[4] Review: D. Scheschkewitz, Chem. Eur. J. 2009, 15, 24762485 .

[5] a) D. Scheschkewitz, Angew. Chem. 2004, 116, 3025-3028; Angew. Chem. Int. Ed. 2004, 43, 2965-2967; b) M. Ichinohe, K. Sanuki, S. Inoue, A. Sekiguchi, Organometallics 2004, 23, 3088-3090; c) S. Inoue, M. Ichinohe, A. Sekiguchi, Chem. Lett. 2005, 34, 1564-1565; d) K. Abersfelder, D. Güclü, D. Scheschkewitz, Angew Chem. 2006, 118, 16731675; Angew Chem. Int. Ed. 2006, 45, 1643-1645; e) M. Ichinohe, K. Sanuki, S. Inoue, A. Sekiguchi, Silicon Chem. 2007, 3, 111-116; f) R. Kinjo, M. Ichinohe, A. Sekiguchi, $J$. Am. Chem. Soc. 2007, 129, 26-27; g) T. Iwamoto, M. Kobayashi, K. Uchiyama, S. Sasaki, S. Nagendran, H. Isobe, M. Kira, J. Am. Chem. Soc. 2009, 131, 3156-3157.

[6] a) D. Scheschkewitz, Angew. Chem. 2005, 117, 3014-3016; Angew. Chem. Int. Ed. 2005, 44, 2954-2956; b) T.-1. Nguyen, D. Scheschkewitz, J. Am. Chem. Soc. 2005, 127, 1017410175 ; c) S. Inoue, M. Ichinohe, A. Sekiguchi, Angew. Chem. 2007, 119, 3410-3412; Angew. Chem. Int. Ed. 2007, 46, 3346-3348; d) I. Bejan, D. Güclü, S. Inoue, M. Ichinohe, A. Sekiguchi, D. Scheschkewitz, Angew. Chem. 2007, 119, 3413-3416; Angew. Chem. Int. Ed. 2007, 46, 3349-3352; e) K. Abersfelder, D. Scheschkewitz, J. Am. Chem. Soc. 2008, 130, 4114-4121; f) I. Bejan, S. Inoue, M. Ichinohe, A. Sekiguchi, D. Scheschkewitz, Chem. Eur. J. 2008, 14, 71197122; g) S. Inoue, M. Ichinohe, A. Sekiguchi, Chem. Lett. 2008, 37, 1044-1045.

[7] J. Baumgartner, R. Fischer, J. Fischer, A. Wallner, C. Marschner, U. Floerke, Organometallics 2005, 24, 64506457. 
[8] M. Weidenbruch, K. Schäfers, K. Peters, H. G. von Schnering, J. Organomet. Chem. 1990, 381, 173-181

[9] a) T. P. Lockhart, W. F. Manders, Inorg. Chem. 1986, 25, $892-895$; b) S. Adams, M. Dräger, J. Organomet. Chem. 1987, 323, 11-20.

[10] G. Casella, F. Ferrante, G. Saielli, Inorg. Chem. 2008, 47, 4796-4807.

[11] Review: M. Weidenbruch, Chem. Rev. 1995, 95, 1479-1493.

[12] H. Suzuki, K. Okabe, S. Uchida, H. Watanabe, M. Goto, J. Organomet. Chem. 1996, 509, 177-188.

[13] V. Y. Lee, M. Ichinohe, A. Sekiguchi, J. Organomet. Chem. 2003, 685, 168-176.

[14] SMART, SAINT, SADABS, Siemens Analytical X-ray, Instruments Inc., Madison, Wisconsin USA, 1999.

Received: ((will be filled in by the editorial staff)) Published online: ((will be filled in by the editorial staff)) 